\title{
A gramática moral de uma lenda contemporânea
}

\author{
The Moral Grammar \\ of a Contemporary Legend
}

\author{
Giulle Vieira da Mata \\ Departamento de Ciências Sociais. \\ Universidade Federal de Ouro Preto. Brasil
}

\section{RESUMO}

Nas lendas aqui analisadas, dois irmãos são os representantes morais de "Sua cultura". Eles "corporificam" idéias e definições morais no mundo social. Neste artigo, analisaremos como os Irmãos Piriás se tornam alvo da atenção dos membros de uma comunidade narrativa específica. Por meio dos personagens de suas lendas, a comunidade legitima um modo específico de existência, promovendo o debate público em relação à importância de seu papel e de sua função social.

Palavras-chave: Lendas contemporâneas, Valores, Relato moral, Brasil.

\section{SUMMARY}

In these legends two brothers are identified as moral representatives of "their culture". As characters of legends they give existence to ideas and moral definitions in the social world. In this article, we analyze how the Piriás Brothers became the focus of attention of a specific community narrative. Through the characters of their tales, the members of this community gives legitimity to a specific mode of existence. This is done in the course of the narrative moment, when it occurs a public debate on the importance of the social function and role of characters and narrators is promoted.

Key words: Contemporary Legends, Values, Moral Discurse, Brasil.

Um fato acontecido no mês de abril do ano de 1978 provocou e ainda provoca comentários em Sete Lagoas (70 km. de Belo Horizonte, Minas Gerais) e região. Depois de um "incidente" envolvendo a polícia, os irmãos Sebastião e Orlando Patrício da Costa tornaram-se celebridades e sua fama se espalhou. Um registro destacado do contexto de comunicação em que a narração do "caso" sempre se dá seria mais ou menos assim:

Os Piriás eram dois irmãos que teriam ido para Sete Lagoas atrás de trabalho, vindos da região da Serra do Cipó. Na cidade, teriam pegado de empreitada uma cerca pra 
fazer na fazenda de Seu Culego. Terminado o serviço, o fazendeiro (que era turco) não teria pago, porque achou que o serviço foi feito rápido demais. Os irmãos, então, começaram a cobrar insistentemente. O fazendeiro teria se sentido ameaçado e chamado a polícia. Resultado: um dos irmãos foi preso, acusado de roubo de um rádio. Depois de solto, junto com o irmão, voltaram a cobrar do fazendeiro, que teria chamado a polícia novamente. Na fuga, os dois acabaram por matar um policial com um tiro no meio da testa lá na Lapa da Branca, onde é hoje o bairro Padre Teodoro. A polícia iniciou então uma perseguição aos Piriás que durou mais de seis meses, dentro de uma área compreendida ao sul por Sete Lagoas e ao norte por Diamantina. Os dois eram excelentes mateiros. Conheciam bem as redondezas e escapavam com facilidade. Chegaram a matar vários policiais. A polícia só conseguiu matar os dois na noite de natal daquele mesmo ano.

Ainda pode-se recolher um ou outro detalhe nos termos do "é o povo quem diz": a prisão do irmão cujo apelido era Caolho foi realizada a mando de um fazendeiro poderoso, ex-patrão dos Piriás. Na prisão os moços teriam apanhado muito, chegando um deles a ser castrado, ouviu-se dizer. Daí o ódio e a vingança: "por isso é que eles só matavam policiais", afirma-se aqui e ali. Os Piriás eram exímios atiradores e só matavam com tiro na testa. Tinham o corpo fechado (disso praticamente ninguém duvida). Eram anfíbios, podendo ficar horas embaixo d'água. Conseguiam percorrer léguas e léguas em um só dia. Na fuga, podiam se transformar em cupim, arbustos e até mesmo em policiais, com farda e tudo, e era assim que conseguiam informações sobre diligências futuras. A bússola dos dois era o rádio à pilha, que informava dos passos da polícia. A sua guardiã mais fiel era uma cadela, que os policiais teriam matado covardemente. "E que morreram que nada!" - ouve-se sempre, e em seguida a explicação: na verdade, a notícia da morte dos Piriá teria sido plantada pela polícia para abafar a vergonha de ter sido desmoralizada por dois caboclos analfabetos, falase quase em sussurro.

O drama dos Piriás virou assunto na cidade, suscitando as mais variadas formas de expressão. Um cordel e uma novela foram escritos. Dois filmes (um curta e um longa metragem) foram rodados e há o projeto de um terceiro. Para além da região, os Piriás foram notícia até mesmo no Jornal Nacional. A imprensa mineira deu grande destaque ao caso. Não faltou espaço sequer para as lendas:

[...] a fama dos irmãos Orlando e Sebastião Patrício cresceu assustadoramente na zona rural de Sete Lagoas. Em todos os locais de reunião, se contavam estórias sobre os dois irmãos. Uma das lendas mais contadas, e que logo correu de boca em boca, dava conta de que Orlando e Sebastião viviam no mato há muito tempo, desde o dia em que teriam assassinado a própria mãe. Esta, pouco antes de morrer, teria lançado uma praga nos filhos, dizendo que eles iriam passar o resto de suas vidas como animais selvagens, dormindo no mato e perseguidos, sem poder dormir duas noites no mesmo lugar.

Outra estória que logo se tornou popular falava que eles tinham corpo fechado e parte com o diabo e por isso nunca seriam feridos pelas balas disparadas contra eles. Esta versão surgiu em virtude da maneira usada pelos Piriás para fugir aos constantes cercos. Atirando sempre e rodopiando o corpo sobre si mesmo, eles tentavam se transformar num alvo difícil para os militares que os caçavam. Além disso, a pontaria sempre certeira de um dos Piriás era motivo de conversa em todos os locais e o povo começou a criar um mito em torno de seus nomes.

[...] Algumas pessoas diziam que a guerra que Orlando e Sebastião travavam contra a polícia fora causada por maus tratos recebidos durante a prisão, e que teria deixado cego um 
deles. Desde esse dia, eles teriam feito um juramento de lutar até a morte contra qualquer policial e não maltratavam as pessoas que encontravam em seu caminho ${ }^{1}$.

Histórias como estas comunicam uma moral, constituem algo como um Moral-Discurse (Stehr 1998). Configuram estratégias de moralização, uma tentativa de formação de uma opinião "pública" ${ }^{2}$. Delas se vale para elogiar ou satirizar, criticar ou incentivar. Configuram um gênero narrativo, marcado por um ininterrupto desdobramento do significado atribuído a um determinado evento. Nesse sentido, todas essas histórias são resultado e, ao mesmo tempo, instrumento de formalização da relação de uma "comunidade de comunicação" com um dado acontecimento. Uma formalização que depende de uma tomada de posição no que diz respeito aos critérios de avaliação de conduta dos sujeitos envolvidos naquele evento. Essa tomada de posição se revela tanto na maneira como as pessoas descrevem a atitude dos personagens das lendas quanto na forma e na escolha do momento de narrar.

Enquanto personagens, os dois irmãos incorporam crenças, doutrinas convicções morais em seus atos. Cada uma de suas características lhes é como que imposta de fora: advém, na verdade, do modo como aqueles que narram suas histórias consideram e usam os personagens para entender e avaliar a sociedade em que vivem e, por conseguinte, a si mesmos e as formas de sociação em que estão envolvidos. Assim, os Piriás se tornam alvo da atenção dos membros da comunidade narrativa proporcionando a ela um ideal cultural e moral, legitimando seu modo específico de existência baseado no valor do cumprimento de promessas, da justiça e da coragem como virtudes inegociáveis.

Esse esforço de atualização desses valores como definidores do horizonte moral da comunidade narrativa evidencia a presença de uma dupla perspectiva moral que enseja o confronto entre formas de insititucionalização de valores no passado e no presente aos quais a lenda se refere e entre os quais a lenda promove o encontro. $\mathrm{Na}$ narração, a busca é por um acordo à respeito da definição de virtudes e vícios e sua atualização no presente.

Nas lendas, os Irmãos Piriás são apresentados como homens que agem conforme esquemas de tipificação de pessoas e ações constituídos pela comunidade narrativa a partir da categoria trabalhador. É a condição de trabalhador que fixa aos dois as metas dignas de estima por parte dos interlocutores da lenda. É por meio dessa categoria que a comunidade narrativa diz o que os Piriás fazem, e por conseguinte, quem eles são (já que, nas lendas, ações são interpretáveis a partir de condutas). O que faz dos Piriás "tipos", e ao mesmo tempo impede que se vejam neles indivíduos ou mesmo membros de um segmento social específico.

(Con)formados na e pela condição de trabalhadores, os irmãos Orlando e Sebastião constituem verdadeira encarnação de valores associados a essa condição, sendo o "trabalhador" entendido pela comunidade narrativa como qualidade do indivíduo corajoso, honesto, ordeiro e diligente.

\footnotetext{
${ }^{1}$ Diário da Tarde, 27/12/1978.

${ }^{2}$ Uma excelente análise dessas modernen Sagen em sua função de moralização foi feita por Johannes Stehr (1998). Devo muito de minha argumentação, nesse particular, à leitura desse livro, escrito a partir do que há de mais recente nos assim chamados cultural studies.
} 
«Eu conheço eles desde meninos, gente boa que quando pegava no serviço era pra valer" - testemunhou há 20 dias o sitiante Isidoro Cunha, 42 anos, o "Nonô Cunha" de Sete Lagoas. E o fazendeiro Manoel Cirilo, de 73 anos, em cujas terras fica a "Lapa Branca", grota onde os Piriás moraram alguns meses, atestou, por sua vez: «eles nunca me deram amolação no tempo que moraram ali" - diz apontando uma montanha de pedras cerca de um quilômetro de extensão - "não eram gente ruim não. Eram gente de bem, trabalhadora. Parece que ficaram bandidos por judiação da polícia ${ }^{3}$.

No mesmo sentido seguem as lendas, onde os interlocutores se referem aos Piriás como "valentes para o trabalho", homens que "não recusavam serviço, "não escolhiam serviço", "bons de serviço" e "muito trabalhadores". Evidentemente, o uso desses termos não é meramente retórico. Neles deve-se reconhecer o esforço dos interlocutores da lenda em firmar a condição de trabalhador como pré-requisito do reconhecimento social. A partir dessa idéia ampliada do tipo "trabalhador", os interlocutores da lenda descrevem para os dois irmãos uma autêntica ética do trabalho como fundamento do que poderíamos chamar invulnerabilidade moral dos protagonistas das lendas.

Daí a lenda configurar uma espécie de legitimação cotidiana de princípios de distribuição de reconhecimento social a partir da categoria trabalhador ${ }^{4}$. Essa ética do trabalho elaborada na lenda opera como uma ideologia para uma "nova" ordem, definindo os limites do poder da polícia bem como do fazendeiro que parecem partir do princípio do não-valor de trabalhador-cidadão dos Piriás, já que nas lendas agem contra os irmãos como se eles fossem subgente, desqualificando-os como merecedores de "consideração" ou dignidade. A ação policial a mando do fazendeiro rico é lida na lenda, por isso mesmo, como uma imposição objetiva, fria (que não leva em conta a ação e qualidades individuais). Nos termos da lenda, mais que ignorar o princípio de igualdade do direito abstrato, o grande erro daqueles que se acreditam acima da lei devido à sua posição na escala social é ferir a ordem moral considerada legítima pelos outros, vítimas de seus desmandos. Acima da lei, nas lendas, estão o fazendeiro e a força policial, identificados pelos termos "o rico" e "a polícia". O rico e a polícia são tomados como referentes "típicos" de uma ordem peculiar cuja base é composta por uma verdadeira "ralé" de subcidadãos (Souza 2003), estes sob constante ameaça $^{5}$. Nas palavras de uma moradora do Maquinezinho, distrito de Pirapama:

\footnotetext{
${ }^{3}$ Jornal Estado de Minas, 10/08/1978.

${ }^{4}$ Necessário aqui ressaltar nossa dívida com o argumento de Jessé Souza (2003) sobre a redefinição da condição de cidadão a partir da categoria "trabalhador". No discurso comum do brasileiro, o trabalhador não pode nem deve ser confundido com "vagabundo", "malandro", "preguiçoso". Merece ser "reconhecido", e contra ele não se deve cometer nenhuma injustiça. A partir do argumento de Souza podemos considerar que mais que defender o trabalhador como merecedor da dignidade fundamental da cidadania em termos jurídicos, o que ocupa a lenda é o reconhecimento do trabalhador em termos sociais.

${ }^{5} \mathrm{O}$ mesmo pode ser observado nas lendas sobre Lampião. Em momento narrativo registrado em 11/01/2007 (Maquinezinho, Distrito da cidade de Cordisburgo, próxima a Sete Lagoas). Neste momento narrativo, quando a categoria "trabalhador" foi acionada na conversa sobre Piriás, o outro nome que veio à baila foi o de Lampião. Segundo o informante, Lampião teria vivido uma história muito parecida com a de Orlando e Sebastião. Seu mal era raiva de gente rica e da polícia. Nas suas palavras, "Lampião não gostava de rico também não. Era igual Piriá mesmo. E de polícia, nem se fala. A polícia fez Lampião. E ela também é que trouxe a má fama dos Pirián. Todos os presentes assentiram moralmente em acordo.
} 
O medo é bom companheiro. E há que se ter medo de estranho, de rico e de polícia. É gente que a gente não consegue se percebê bem. Aqui o medo de Piriá era medo de estranho. No caso dos moços, o angu de caroço todo foi que ele enranxô com a polícia e com home rico. O bom conselho diz que não mexesse com gente rica não, nem com polícia. Era gente boa. Só não gostava de polícia nem de gente rica ${ }^{6}$.

Em oposição ao trabalhador, o rico e a polícia. A luta de classe é evidente e a mensagem de sua narrativa, clara, em favor daqueles para quem Marx descreveu um futuro de herói:

Ideal, menina, é não se envolvê nem com rico, nem com polícia. Mas os Piriá quebraro essa regra e deu no que deu. A polícia passô foi vergonha. E o rico ficô sem nome .

A análise dos sentimentos morais que governam a lenda revela como os critérios para atribuição de reconhecimento social no mundo da vida são tão historicamente contingentes, como culturalmente determinados. Nas lendas, é combatida uma visão de mundo e uma hierarquia valorativa estabelecida: um consenso social implícito, responsável por preconceitos profundos e "invisíveis". É essa percepção mais profunda da própria marginalização e mesmo da invisibilidade social que é canalizada pelas lendas. Uma percepção que se torna reflexiva, deixa de ser subliminar para aparecer simbolicamente articulada na narração e evidenciada para quem dela participa.

É por meio da categoria "trabalhador" que a lenda opera a disseminação efetiva de concepções morais que passam a funcionar como idéias-força no contexto de comunicação. É ordenando os Piriás a esta categoria que todas as ações dos dois irmãos se tornam defensáveis (e são efetivamente defendidas). Até o comportamento desviado da condição de trabalhador pode ser explicado em termos de uma motivação "especial»: os Piriás só roubavam porque, perseguidos pela polícia, não podiam mais trabalhar.

Qual é aquele que estando com fome, com medo de morrer, não roba. Só se fô besta. Eles tava trabalhano, mas a perseguição da polícia impedia eles de continuá no caminho do bom vivề $\hat{~}^{8}$

Encarnando a condição de trabalhadores ideais, os Piriás incorporam, na lenda, uma espécie de autoridade revelada. Autoridade que pode ser facilmente estendida: a forma de ação comum, que tende à evitação do (ou pelo menos à desconfiança em relação ao) rico e da polícia, que implica em conformismo frente ao não-reconhecimento social, não comporta os Piriás. Além de "muito trabalhadores" e eficientes, os Piriás seriam homens indóceis, de (re)ação, gente "brava".

\footnotetext{
${ }^{6}$ Percebe-se claramente na fala do informante um ideal de não-ação orientando sua versão da história. Um ideal que não aparece em outras falas sobre o caso Piriás que tive oportunidade de registrar.

7 Momento narrativo em 10/01/2007, Maquinezinho. Em respeito ao esforço das pessoas em preservar sua identidade, os interlocutores são identificados apenas por letras, quando for necessário diferenciá-los. Já o padrão de linguagem oral é mantido em todos os registros. Todos os registros constam de um arquivo particular, fruto de uma pesquisa de campo realizada ao longo de três anos.

${ }^{8}$ Momento narrativo em uma oficina de automóveis no bairro Boa Vista (Sete Lagoas), em $22 / 05 / 2006$.
} 
Pelo que eu sei, era gente honesta, trabalhadora. A polícia é que fez hora com a cara deles. Acho que eles era aí pra esses lado do Cipó. É gente perigosa, esquentada. O povo desses lado tem fama. Não leva desaforo pra casa. Era o caso dos dois. Mas gente honesta, trabalhadora?.

Os mesmos adjetivos aparecem em outras ocasiões, quando os interlocutores da lenda insistem em representar os Piriás como indivíduos autônomos, sujeitos úteis e dignos, sem outra fonte de recursos que não sua habilidade e disposição para o trabalho.

$\mathrm{X}:-[\ldots]$

A: - A gente tava na barraquinha. E naquela época, quando um rapaz pedia pra conversá com uma moça ela tinha que dá atenção só pra ele. Se ela não conversasse e depois ficasse de papo com outro, era briga na certa.

B: - Meu Deus!

[risos]

G: - E quem quis conversar com quem?

A: - Os Piriá estavam no dia e mandaro recado pra $\mathrm{H}$.

[risos]

B: - Mas tia H., hein?

G: - Que sina, meu Deus. E ela?

A: - Ela não quis. Mas depois S. e C. foram conversá com a gente. S. gostava de H. Aí os Piriá quiseram brigar. E foi um apuro.

B: - Teve barraco?

A: - Quase. Mais falação e empurra-empurra.

[risos]

$G$ : - Eles eram brigões então?

A: - Não, mas eles eram assim mesmo. Todo mundo tinha medo deles. Tinha fama. Um era vesgo e era o pior. O outro era mais calmo.

B: - Era feio?

A: - Rapaz pobre, maltratado. Os fazendeiros que gostava muito deles. Eram muito trabalhadores. Todo mundo falava. Desde novinho.

$G$ : - Mas foi um fazendeiro que mandô prendê os dois.

A: - Foi, mas um só. Teve os outros que ajudaram. Davam comida e munição. Escondia eles.

$\mathrm{X}:-[\ldots]^{10}$.

Neste trecho percebe-se claramente que é a condição de trabalhador que define o horizonte prático-moral que conforma a vida dos dois personagens e suas relações sociais. Toda a série de habilidades e atributos especiais atribuídas a eles (brigões, pavio curto, valentes, corajosos, eficientes, etc.) é inferida a partir do traço distintivo inicial que é a condição de "valentes para o trabalho".

$\mathrm{X}:-[\ldots]$

A: - Pois é! O Caolho era bom de montaria. Eles tinham um circo de tourada e montavam aqui na praça da igreja quando das festa. Eram trabalhadô. Mas de pavio curto. Depois falaram que a polícia judiou com eles. Mas eu não sei se é verdade.

$\mathrm{X}:-(\ldots)$

\footnotetext{
${ }^{9}$ Momento narrativo na casa do informante (Sete Lagoas), em 04/01/2007.

${ }^{10}$ Momento narrativo em 12/07/2007, durante uma conversa sobre os Piriás com membros da família em Sete Lagoas. Minhas intervenções são marcadas com a letra G.
} 
A: - A tourada era de circo. Os Piriá junto com o pai fazia pra ganhá bico. Eles era rapaz de enfrentá qualquer coisa, qualquer trabalho. Foro capaz de enfrentá polícia armada. E eles nem tinha armamento, hein? A polícia ficou desorientada. Não tava acostumada com resposta a desaforo.

B: - O povo confundia a polícia de medo. Não podia denunciá Piriá. Eles não matava civil, mas o povo respeitava. Covardia só fizero com o home em cima do pé-de-laranja. [risos]

B: - Coragem que eles tinha era muita. Coragem de sobra.

A: - Não tinha armamento direito, mas não errava tiro.

B: - Isso é verdade. Ficava um de costa pro outro. Um carregava a arma e o outro mandava chumbo. E ia rodando que nem máquina.

$\mathrm{X}:-[\ldots]^{11}$.

Todas essas características compõem uma estrutura perceptiva e avaliativa do mundo que os interlocutores da lenda criam para os Piriás. Uma estrutura que serve como base para todas as experiências dos dois irmãos, formando um verdadeiro esquema de conduta, ação, percepção e pensamento para esses personagens concebidos como moralmente invulneráveis. Uma condição que eles trazem inclusive marcada no corpo, pois é também por meio da descrição dos traços físicos especiais dos Piriás que os interlocutores da lenda constroem a imagem dos irmãos Orlando e Sebastião.

Dizem que um deles era muito feio, né? Tinha uma cicatriz horrorosa. Era o que atirava melhor $^{12}$.

\section{Outro interlocutor confirma:}

O Sebastião Patrício, o Caolho, era o mais bravo dos dois. E atirava como o demo. Era raiva da polícia porque perseguia eles. Tem aqui um parente deles, um que tem o braço cortado, o tal de Zé Mãozinha. É caolho também. Da mesma índole. Gente brava, paude-espinho que nem o Lucifer ${ }^{13}$.

A condição de cego, caolho, evoca o poder simbólico do Piriá: o cego vê mais ${ }^{14}$.

Um deles era cego de um olho. E cê sabe que o que é cego não precisa fazê mira não porque já é cego dum olho mesmo. Era esse Piriá, um deles, o dito Caolho que atirava como o cão. Diz que atirava e rodava num pé só. E tiro num pegava mesmo ${ }^{15}$.

${ }^{11}$ Momento narrativo registrado em 04/01/2007, em Sete Lagoas.

${ }_{12}^{12}$ Momento narrativo em 03/01/2007, em Sete Lagoas.

${ }^{13}$ Curto momento narrativo ocorrido no dia 14/01/2007 em um posto de gasolina no distrito de Pirapama. Nas lendas, Caolho é o Sebastião, o mais escuro, mais alto e mais novo. Orlando é que é o Gentil. No filme e no cordel sobre os Piriás a relação é invertida: Orlando é identificado como Caolho, e Sebastião como Gentil. Na imprensa, os Piriás eram identificados como nas lendas: "Orlando Patrício da Costa, 20 anos, mulato, forte, $1,65 \mathrm{~m}$, rosto com várias marcas e cabelo ouriçado, e Sebastião Patrício da Costa, 19 anos, claro, $1,70 \mathrm{~m}$, cabelos ouriçados e com um defeito na vista - seu apelido é Caolho - eram acusados pela polícia de praticarem furtos na zona rural e já estiveram presos nas cidades de Sete Lagoas, Pirapama, Pedro Leopoldo e Matozinhos" (Jornal A Gazeta, 09/08/1978). Mesmo na imprensa da capital do estado, Belo Horizonte, os jornalistas não conseguiam distinguir quem era quem.

${ }^{14}$ Sobre a figura do cego na cultura popular em geral, e em especial como figura mística e detentora de todos os saberes, cf. Schenda (1993:131-137).

${ }^{15}$ Momento narrativo gravado em Maquinezinho, dia 9/01/2007. Em uma matéria de jornal, o jornalista relata que Caolho era "descrito pela polícia como exímio atirador e apontado como autor das mortes de policiais. Seu irmão raras vezes foi visto nos confrontos com a polícia, que dedu- 
O poder de "ver para além", atribuído aos Piriás, é destacado em outra narração:

Eles tinha o poder de se unir. Como se virasse um. De costa um pro outro saía atirando que policial só via bala zunino no pé da orelha. De costa um pro outro. Formava o poder de olhá pra todas as direção e de andá confundindo o rastro, como quem tem parte com o capeta ${ }^{16}$.

Esse "poder de olhar para todas as direções" ao mesmo tempo se amplia. Unidos "virados um só", os Piriás são descritos como um ser-duplo. Duas cabeças, quatro mãos, quatro pés e o "poder" de ver mais, correr mais, trabalhar mais, serem mais eficientes em tudo ${ }^{17}$. Assumindo a forma de ser-duplo, os dois eram invencíveis. Só poderiam ser mortos se separados. E é o que se disse mais tarde: somente depois de separar os dois irmãos, ferindo gravemente um deles, é que a polícia conseguiu acompanhálos. Quem explicava era o próprio Capitão José Ivo Gomes de Oliveira, o "Capitão Ivo", em entrevista ao Estado de Minas (24/11/1978).

O povo da região está dando notícia de apenas um Piriá, porque, depois do tiroteio, cada um correu para um lado e eles ainda não se reuniram. Temos certeza apenas que o Gentil está com o braço ferido à bala e bastante infeccionado. Quem nos passou essa informação foi o lavrador que conversou com eles ${ }^{18}$.

Percebe-se claramente que todas as características atribuídas aos nossos protagonistas são descritas no decorrer da narração num verdadeiro processo de construção de personagens a partir de uma (in)corporação de significados morais que torna os corpos dos Piriás um verdadeiro "reservatório de valores" (no sentido de Bourdieu); ou seja, o corpo passa a ser entendido como um operador analógico das hierarquias do mundo social, o que permite que valores se tornem personagens ${ }^{19}$. Seus corpos constituem o sinal externo, visível e imediato da blindagem moral que protege os dois. É essa invulnerabilidade moral que justifica não apenas as características físicas dos protagonistas da lenda, mas também suas ações, seu caráter e sua natureza. Trata-se de uma condição especial que, marcada fisicamente nos dois personagens, permite aos que compartilham das lendas ler nos corpos dos Piriás o que eles fazem, o que eles experimentam, o que se passa com eles, e, por fim, os indícios de sua conduta numa demonstração clara de que, como tipos, eles transcendem a realidade histórica.

ziu que ele funcionava como municiador, o que explicaria a capacidade de fogo que levou a dupla a enfrentar a polícia e a furar vários cercos destinados a capturá-los." Jornal A Gazeta, 30/ 12/1978.

${ }^{16}$ Momento narrativo na Feira do Morro Vermelho, dia 06/01/2007. Até mesmo o capitão de polícia falou à época dessa tática especial dos dois irmãos: "Um deles é exímio atirador. O que não é bom atirador, fica municiando o outro. Isto foi observado pelos soldados durante o tiroteio na pedreira do Paredão" (Jornal Estado de Minas, 08/08/1978).

${ }_{17}$ Para uma análise detalhada da importância da figura do ser-duplo (Doppelwesen) na mitologia grega, em especial no mito de Apolo, cf. Usener (1913: 315-356).

${ }^{18}$ O grifo é meu. Em outras reportagens afirma-se o mesmo: Orlando foi ferido e se separando de Sebastião, sendo inclusive julgado como morto. Para uma reportagem mais completa sobre a questão cf. Jornal $A$ Notícia, 27/12/1978.

${ }^{19}$ Bourdieu citado por Souza (2003: 43). 
A insistência na descrição desses sinais corporais procura evidenciar o caráter extra-ordinário do status moral dos dois irmãos ${ }^{20}$. O defeito físico de Sebastião permite antever sua identidade social. Circulava, aliás, a versão de que ele teria sido castrado.

$\mathrm{X}:-[\ldots]$

A: - Judiaram deles. Pelo menos é o que o povo diz. Tem gente que conta que um deles, o Caolho, foi até capado. Pode tê revolta maior prum home?

B: - Dai que parece tê vindo a força deles. Não era gente de se conformá. Ainda mais num caso grave desse, se é que foi isso mesmo.

A: - Se isso aconteceu mesmo, resta concluí que foi a polícia mesmo que fez eles crescê desse jeito.

$\mathrm{X}:-[\ldots]^{21}$.

A seguir o raciocínio do próprio interlocutor, o Caolho teria se tornado ainda "mais homem", exatamente por ter sido castrado ${ }^{22}$. A castração teria despertado nele o ódio aos que o mutilaram, reforçando, assim seu caráter anterior: ele não é descrito nas lendas como o tipo de homem que se conformava (um "pau mandado", no dizer popular). Antes é aquele que entra em guerra contra a forma de conduta que prevalece em seu meio. A idéia de castração tem diretamente a ver com esse padrão moral de conduta de Sebastião, já que o castrado manteria a consciência de sua masculinidade por meio do ódio e da fúria contra a polícia e os ricos. No caso, em vez de lhe retirar a força, o crime de castração seria a fonte de sua força tanto física quanto moral $^{23}$. O mesmo princípio vale para sua condição de "cego de um olho":

${ }^{20}$ Cf. o conceito de "estigma" para os gregos em Goffman (1982: 11). Lindahl (1996: 78) prefere o termo insígnia. Diríamos, com ele, que os Piriás "must reveal its identity to the wary through one telltale sign".

${ }^{21} \mathrm{O}$ grifo é meu. Momento narrativo registrado em uma madeireira em Sete Lagoas (12/07/ 2007). O boato é citado em uma reportagem do Diário da Tarde (27/12/1978), que começa falando da expectativa quanto ao laudo do IML quanto ao número de tiros que os dois irmãos receberam. E segue: “Há inclusive a curiosidade de se saber se um dos 'irmãos Piriás' tem o órgão genital inutilizado, pois correm boatos de que Orlando e Patrício [sic] passaram ao crime depois de torturados 'por causa de um rádio de pilha comprado legalmente'”. O cordel também menciona a suposta castração do Piriá Caolho: "E depois disso um boato / No arraial circulou: / 'Como se fosse um gato / A polícia lhe castrou / E ele perdeu a força / Virou bicha, virou moça' / - Toda a gente debochou!" (Evangelista e Camargos 1979: 21).

${ }^{22}$ Mary Douglas (1976) advoga que a ênfase no corpo humano é uma forma de simbolizar um conflito social, de maneira que partes do corpo se tornam sinedoques para o corpo como um todo, e o corpo, em si, sinedoque para o grupo. Nesse sentido, a castração poderia ser interpretada como um crime contra os vários corpos que compõem um coletivo; e a reação dos Piriás ao suposto crime de castração como símbolo de uma reação coletiva contra a polícia.

23 Diferentemente do boato de que "O Piriá mais claro e mais alto" teria sido visto vestido de mulher. Um rumor que tentaram implantar na cidade, mas sem sucesso. Ao ler a reportagem "Sebastião desfilou vestido de mulher?" (Jornal A Noticia - 10/08/1978), percebe-se claramente a intenção de se ridicularizar o Piriá repetindo-se a estratégia utilizada com Leonel Brizola que, segundo o folclore político conservador, teria fugido do Brasil vestido de mulher. Um ex-empregado da olaria no bairro Progresso, lugar de onde, segundo o jornal, teria surgido a "informação", me disse que não houve nada disso. "Na época não me lembro de ninguém na olaria falar que o Piriá tivesse vestido de mulher. A gente chegou a ver mesmo os dois pelos matos ali, mas com saco nas costas os cano das arma pra fora. Um deles pediu cigarro. A gente desconfiô que era Piriá e deu." (Momento narrativo na praça do Bairro Progresso em 10/07/2007). Ao contrário de Brizola, a história não aderiu à pele do Piriá. 
O certo é que os irmãos Piriás conseguiram ganhar ajuda dos moradores, que por medo ou amizade, lhes forneciam comida e davam informações sobre o deslocamento dos soldados. Algumas pessoas diziam que a guerra que Orlando e Sebastião travavam contra a polícia fora causada por maus tratos recebidos durante uma prisão, e que teria deixado cego um deles. Desde esse dia, eles teriam feito um juramento de lutar até a morte contra qualquer policial e não maltratavam as pessoas que encontravam em seu caminho ${ }^{24}$.

Note-se que o "poder" de Sebastião Caolho está estreitamente relacionado com o fato de ele ter estado na prisão - inclusive no DOPS, que, no imaginário urbano da época do Regime Militar, tornou-se uma espécie de região inacessível, um lugar para além dos limites da sociedade. Ao ser preso, Caolho foi colocado "fora" do sistema social normal e a lenda registra esse momento de qualidade ritual, no qual poderes lhe são "atribuídos". A façanha de Caolho foi ter estado neste espaço liminar e retornado dele: "disforme", mas investido de poderes especiais ${ }^{25}$. Exatamente por isso é que, nas lendas, Sebastião é o mais forte, o mais alto, o Caolho, o castrado, o marcado por cicatrizes, o mais feio, o mais corajoso, o mais audacioso, o que atira melhor. Mais ainda: sua mãe teria morrido quando lhe deu à luz. Daí sua sina de matador. É aquele que esteve na prisão, o que passou por uma espécie de morte ritual e foi capaz de renascer, concentrando em si "todo o poder". É o que jura vingar o irmão Gentil e assume a responsabilidade de defendê-lo. É nesse "se juntaram e juraram vingança" que as qualidades do Caolho contaminam o Gentil.

À medida que essa dupla é investida de poderes nas lendas, os interlocutores vão debatendo sobre formas sociais e valores. Todas essas características, de certa forma, desviantes, "fora do padrão", vão adquirindo valor simbólico generalizado. As pessoas que ouvem as histórias supõem, quase automaticamente, que os Piriás possuem muitas outras características facilmente associáveis. É o que se pode perceber nas falas a seguir.
$\mathrm{X}:-[\ldots]$
$G$ : - A confusão foi grande então?
A: - Foi. Dizem que o trem todo foi um só. Eles compraro um rádio, que a polícia tomô deles e falô que eles era ladrão. Mas eles não mexia com ninguém não.
$G$ : - Eles não eram ladrão?
A: - Da onde? Era gente trabalhadora. A polícia é que cismô, né B?
B: - É. Cismô com eles aí na rua.
G: - Mas cismô por quê?
A: - Eles andava de cabelo grande, né? Fora do padrão, né?
B: - É! Pobre, né?
A: - Mas era gente honesta. E atirava era bem. De repente eles colava as costa um no outro e saía rodando. Rodando e atirando. Eles via tudo e polícia não via nada.
$\mathrm{X}:-[\ldots]^{26}$.

Como já disse, penso que o processo de simbolização se amplia a partir da necessidade se ratificar o caráter extra-ordinário do status moral dos Piriás, de maneira

\footnotetext{
${ }^{24}$ Jornal Diário da Tarde (27/12/1978).

${ }^{25}$ Mary Douglas sustenta que "O homem que retorna dessas regiões inacessíveis traz consigo um poder inacessível àqueles que tenham permanecido sob o controle de si mesmos e da sociedade. [...] Ter estado nas margens é ter estado em contato com o perigo, é ter ido à fonte de poder" (Douglas 1976: 118-120).

${ }^{26}$ Momento narrativo registrado em uma madeireira em Sete Lagoas (12/07/2007).
} 
que até a descrição da estratégia de combate dos dois se faz em termos do extracotidiano. Unidos na forma de um ser-duplo, os Piriás se tornam invencíveis. Uma invencibilidade - militar e moral - que só pode ser superada por meio do recurso à traição.

Até onde eu sei os dois morreram numa tocaia da polícia. Já andavam pelos lado de Corinto, lugar que não conheciam tão bem. Um deles ficou gravemente ferido por causa de um tiro que atingiu ele numa luta lá pros lado do rio Jabuticaba. Foi salvo por um aguacero que despencou do céu. Eles vestiram um tronco de madeira com roupa e a polícia achô que tinha apanhado um Piriá. Mas não apanhô não. Um irmão apoiado no outro, conseguiram seguir. Aí parece que encontraram na estrada um policial disfarçado de trabalhadô, montado num burro, não sei, que disse pra eles seguir a linha do trem. Eles não conheceram que era policial e caíram na armadilha. Morreram furado que nem penêra ${ }^{27}$.

Por ocasião de uma entrevista na capital, um jornalista fez a pergunta que não poucos interlocutores da lenda queriam ver respondida.

- Major, eles não teriam sido atingidos pelas costas?

- Não. Eles foram atingidos a partir do $\operatorname{cerco}^{28}$.

Em sua resposta, o major Jurandir Afonso Marinho afirmou que chegou a gritar aos Piriás para que eles se entregassem, recebendo tiros como resposta. Os dois teriam furado o cerco e acabaram se afastando um do outro. O Caolho teria sido abatido primeiro, e seu irmão cerca de $50 \mathrm{~m}$ à frente ${ }^{29}$.

As declarações do major não surtiram o efeito esperado. Pelo contrário, pareciam corroborar os termos das lendas. As pessoas continuam dizendo que os Piriás foram enganados por um policial à paisana que os teria induzido ao erro, fazendo com que caíssem numa emboscada, sendo Caolho morto primeiro. Somente depois, sem a proteção de seu tutor, Gentil teria tombado. É o que se diz. Exatamente como os dióscures gregos, os Piriás só poderiam ser mortos à traição e depois de separados um do outro. Tudo se passa como na trama de Hércules, que jurou vingança depois de perder a luta para Eurytos e Kreatos: o filho do todo poderoso Zeus só conseguiu matar os dois irmãos pelas costas, num momento em que os dois se encontravam separados (Usener 1913). ${ }^{30}$

A imputação de atributos sobrenaturais aos protagonistas da lenda segue então. Os Piriás são apresentados como homens encantados, que possuem o dom da metamorfose e da ubiqüidade.

${ }^{27}$ Momento narrativo com um ex-vizinho, quando de uma visita à sua casa em Sete Lagoas, em 16/10/2004. Sua fala parece se confirmar numa reportagem do Estado de Minas (24/11/1978): "Ai houve o encontro do cabo Nestor com os Piriás. O cabo estava montado numa mula e ele conversou com os dois. Explicou que estava procurando gado e a conversa terminou em discussão. Os Piriás diziam que a fazenda era deles".

${ }^{28}$ Entrevista coletiva concedida pelo Major que coordenou a operação que resultou na morte dos irmãos Orlando e Sebastião. Jornal Diário da Tarde (27/12/1978).

29 Cf. também edição do Estado de Minas (27/12/1978).

${ }^{30}$ No caso do famoso social bandit Lampião, teria acontecido algo parecido. Reza a lenda que o cangaceiro só foi morto quando se separou de Corisco, seu amigo-irmão, numa emboscada armada pela polícia. 
A velha Natividade Pereira dos Santos levanta a mão enrugada e diz para a jovem jornalista da TV Globo: "Eles têm parte com o sujo. Andam feito bicho do mato e ninguém pega eles fácil, não [...]. Para outros, eles têm o corpo fechado e conta-se que o soldado Gastão descarregou neles seu revólver à queima-roupa sem, contudo acertar um tiro ${ }^{31}$.

Algo que se justifica também na identidade homem/animal expressa na alcunha escolhida para os dois como justifica um informante.

O nome deles se formô assim de preá, pereá, priá, até virá piriá. Tem história de que, desde criança eles desmontavam guarda-chuva pra fazer espingarda. E eles caçavam preá, aquele coelhinho, pra comer. Um bicho esperto. Eles eram espertos, pequenos, cabelo gafurina $^{32}$.

A identidade entre os dois irmãos e o animal conhecido como preá é realçada em várias outras ocasiões ${ }^{33}$.
$\mathrm{X}:-[\ldots]$
C: - Quem pôs o nome Piriá foi a polícia.
G: - E o que é Piriá?
A: - Piriá é um coelhinho que dá sempre em lugá de brejo.
C: - Na beirada desse corgo aí tem demais, ô.
G: - E por que Piriá?
A: - É um bicho esperto demais. É mais esperto que coelho. Difícil de pegá.
C: - É um rato grande o piriá.
A: - Não. O piriá é mais encorpado que o rato. O rato é fino. O piriá é mais grosso, e muito mais esperto que o rato.
B: - Agora, esse negócio de Piriá de corpo fechado parece mais crendice antiga.
$\mathrm{X}: \quad[\ldots]^{34}$.

Diferentemente do que poderia sugerir a fala dos interlocutores, o nome Piriá não é empregado por causa de sua etimologia. O que importa em sua adoção é a força de seu status semântico. Nas lendas, o nome Piriá emerge da ação dos dois irmãos em uma nova significação. Poder-se-ia falar até num novo campo lexical, onde palavras e atos equivalem-se absolutamente, e até mesmo as qualidades inatas de Orlando e Sebastião Patrício são valorizadas como algo pré-traçado como fica claro no decorrer da narração a seguir.

$\mathrm{X}:-[\ldots]$

B: - Isso é verdade. Ficava um de costa pro outro. Um carregava a arma e o outro mandava chumbo. E ia rodando que nem máquina.

A: - Por isso é que chamava eles de Piriá. Por causa do Piriá esperto do arrozal.

B: - Eles plantava arroz, que é uma trabalhera danada. E treinaro de porvera matando aquele bichim esperto como curisco que atacava a plantação. E mataro foi muito. Por isso foro chamado Piriá. Era esperto como um bichim daquele. Vale dizê que os Piriá viraro Piriá matando piriá e defendendo o que era seu.

\footnotetext{
${ }^{31}$ Jornal A Gazeta (09/08/1978).

32 Entrevista, Sete Lagoas (30/03/2005). Já segundo reportagem do Estado de Minas (09/08/ 1978), lavradores deram o nome Piriás aos dois irmãos porque Orlando e Sebastião se alimentariam preferencialmente do animalzinho - o preá. Daí sua habilidade de viver no mato como preás.

33 Sobre a identidade homem/animal como característica peculiar do herói que consegue fugir aos perigos do outro mundo, ver Propp (1997: 241-258).

${ }^{34}$ Momento narrativo registrado em 03/01/2007.
} 
A: - É porque aquilo cai numa roça de arroz, arrasa tudo e não tem quem pegue. $\mathrm{X}:-[\ldots]^{35}$.

A descrição das fugas dos Piriás também vai ganhando caráter espetacular. Grutas e lapas são moradas prediletas dos dois irmãos encantados. E não é exagero dizer que, nesse caso, grutas e cavernas são vistos pelos interlocutores das lendas como o além-lugar; um lugar de passagem: tal qual Lázaro, na gruta se entra morto para sair vivo $^{36}$.

Outras vezes fala-se de uma maldição como destino:

- Não sei se é verdade, mas corre por aqui um boato de que eles mataram a mãe. Já ouvi também que a mãe jogou uma praga nos meninos. Segundo contam, ela disse que eles só conseguiriam ter sossego se matassem sete policiais. Três eles já mataram.

Esta lenda, contada pelo soldado Valter Lúcio, é confirmada pelo comandante da $3^{\underline{a}} \mathrm{Com}$ panhia do $3^{\circ}$ Batalhão da Polícia Militar, mas de outra maneira. Disse o Capitão José Ivo que ouviu falar na praga.

- A mãe deles afirmou que os filhos não conseguiriam dormir nem dois dias no mesmo lugar ${ }^{37}$.

Os episódios vão ganhando força e distinção de mito, onde a magia é toda uma ambiência. Eis o depoimento de uma esposa de policial reformado:

$\mathrm{X}:-[\ldots]$

A: - Diz que ficava de frente com a polícia assim ó, e que, de repente, eles sumiam. Então o povo conta que eles tinha corpo fechado. Que a polícia atirava neles e eles não... bala não pegava neles. Que eles tinham rezas que eles aprenderam com os escravos, o povo que veio da África, do quilombo daqui de perto. Era o povo mais antigo que então ensinava as rezas pra eles. Então eles tinham rezas que eram rezas que faziam as pessoas ficarem bobas quando eles chegavam perto. Quando eles chegavam num lugar, então eles entravam, comiam. Mas diz que eles não fazia maldade com ninguém não. Diz que eles entrava, comia e chegava até a trabalhá nas fazenda, mesmo depois de tudo. Mas toda vez que encontrava com a polícia era tiroteio mesmo. E aí eu lembro que mandaram buscar reforços em Diamantina, Belo Horizonte. Diz que veio muito reforço pra ajudá a pegá esses home, mas que não tinha jeito. A polícia não punha a mão neles de jeito nenhum. Diz que na hora que via, que sabia onde que eles estava era troca de tiro, que eles trocava tiro com a polícia e que eles atirava pra matá e matava mesmo quem aparecia de farda na frente deles. E eles sumia. Neles a polícia não conseguia atirar de jeito nenhum. Eles rezava. Aprenderam a reza de São Marco, São Cipriano e tinha uma outra, gente, que diz que punha o povo meio bobo. São Marco, São Cipriano e a outra eu esqueci o nome da outra reza que diz que ele rezava, era brava também e punha a pessoa mansa, bobinha. E aí eles chegava, entrava, comia e ia embora sem ninguém dá fé. Qual era o nome da reza, meu Deus?

\footnotetext{
${ }^{35}$ Momento narrativo registrado em 04/01/2007.

${ }^{36}$ Não custa recordar ao leitor o colorido especial que a história local empresta a esta imagem: em Sete Lagoas, lugares como lapas, grutas, grotas e cisternas estão estreitamente associadas à idéia de morte. Ao mesmo tempo, contam-se histórias fantásticas sobre aqueles que retornaram desses "além-lugares" vivos, como nos casos dos crimes de Angueretá e da Gruta do Pião, famosos na região.

${ }^{37}$ Estado de Minas, 10/08/1978.
} 
$G$ : - São Bento?

A: - São Bento! São Bento! São Bento! É isso! São Bento.

G: - Minha vó falava dessa reza. Ela sabia. Rezava pra amansar quem estivesse muito bravo.

A: - É isso mesmo. São Bento. E até hoje... eu quando estava conversando com esse menino, esse policial, esse Surubim, que ele também foi caça Piriá e que ele tomô tiro dos Piriá e tinha chumbo no corpo de Piriá. Até ele, que um dia eu tava conversando com ele, ele disse: "Os home parecia o capeta. A gente tava de frente com eles assim ó, de frente, e os home sumia assim, ó, no meio das pedra, no meio das árvore". Que diz que eles sumiam, sumiam assim como... como se tivesse um trem. E ele ainda falô comigo assim ó, que contam que até hoje ninguém sabe se eles realmente morreram. Ninguém sabe se eles morreram realmente, porque sumiram.

$\mathrm{X}:-[\ldots]^{38}$.

Os interlocutores falam de "corpo fechado". A história do fechamento é de domínio público, sendo narrada, como já vimos, em detalhes. O poder dos Piriás advém, em grande medida, da sua intimidade com aquilo que Durkheim (1989: 488) chamava de o "sagrado nefasto".

$\mathrm{X}:-[\ldots]$

A: - (...) Eles virava cupim. Foi o pai deles, né, B?

B: - É! Tinha esse negócio de vera. Que o pai deles sabia muita coisa, muita reza, recurso de oração.

A: - Reza brava que fechava o corpo. Diz que eles não passava debaixo de cerca. O pessoal falava muito disso.

G: - Por quê?

A: - É que passá debaixo de cerca desfaz, né?

B: - É! Desfaz o fechamento.

A: - Um parente de um conhecido, lá em Paraopeba morreu assim. Numa troca de tiro ele pulô a cerca. Foi na hora. Morreu agarrado na cerca. E não pode passá não.

$\mathrm{X}:-[\ldots]^{39}$.

É um informante natural de Santana de Pirapama, quem explica:

Pra pegá Piriá, só debaixo de arame ou debaixo d'água ${ }^{40}$.

Ou como teria declarado à época o próprio pai dos Piriás, Antônio Patrício dos Santos:

Eles só serão mortos se a polícia pegar eles debaixo de uma cerca, em cima de uma ponte ou numa encruzilhada ${ }^{41}$.

\footnotetext{
${ }^{38}$ Momento narrativo registrado em Sete Lagoas (05/01/2007).

${ }^{39}$ Momento narrativo registrado uma madeireira em Sete Lagoas (12/07/2007). Nas versões da lenda em que se admite que os Piriás de fato morreram, o lugar da morte é sempre um lugar liminar, uma fronteira: tombaram atravessando uma cerca, dentro de uma bueira ou de um rio, debaixo de uma ponte ou numa encruzilhada. Há também uma versão em que se conta que Caolho, antes de morrer, teria traçado um círculo no chão, com o facão, em torno de si (tal qual os amansadores de gado, que traçam no chão um círculo mágico ou uma estrela de Davi para prender boi bravo). Esta cena é descrita também no cordel. Cf. Evangelista e Camargos (1979: 38).

${ }^{40}$ Momento narrativo na fila de atendimento de hospital, Sete Lagoas, 04/01/2007. Igualmente interessante é a fala seguinte: "A polícia cortou o cabelo dele com facão". A semelhança com o mito de Sansão não é mera coincidência. Sobre o cabelo como a parte do corpo que concentra a força e para uma análise de seu simbolismo a partir da "idéia de participação", cf. Röhrich (1966: 55).

${ }^{41}$ A Gazeta, 09/08/1978.
} 
A condição de irmãos também reforça a qualidade mágica, a verdadeira força mística dos protagonistas da lenda. Os dois representam, na lenda, uma unidade. E isso a tal ponto que nem sempre as pessoas sentem a necessidade de distinguir um do outro. É comum que os interlocutores não usem da forma plural para se referir aos irmãos. A forma singular indica, sempre que se convém, que os Piriás não são considerados como indivíduos num sentido pleno. São, na verdade, uma personalidade social única. Uma unidade que ultrapassa a dualidade física e que chega mesmo a superá-la.

A união entre os irmãos adquire valor simbólico amplificado na medida em que é reforçada diante da ameaça de forças externas (Girard 1990:17-19). Nem mesmo o destaque que se confere, nas lendas, à figura de Sebastião (o Caolho, o mais bravo, o mais valente, o que tinha a melhor mira, etc) é capaz de perturbar esta unidade. Mas como explicar, então, o destaque concedido à figura de Sebastião? Penso que, a partir de Morin (1997:

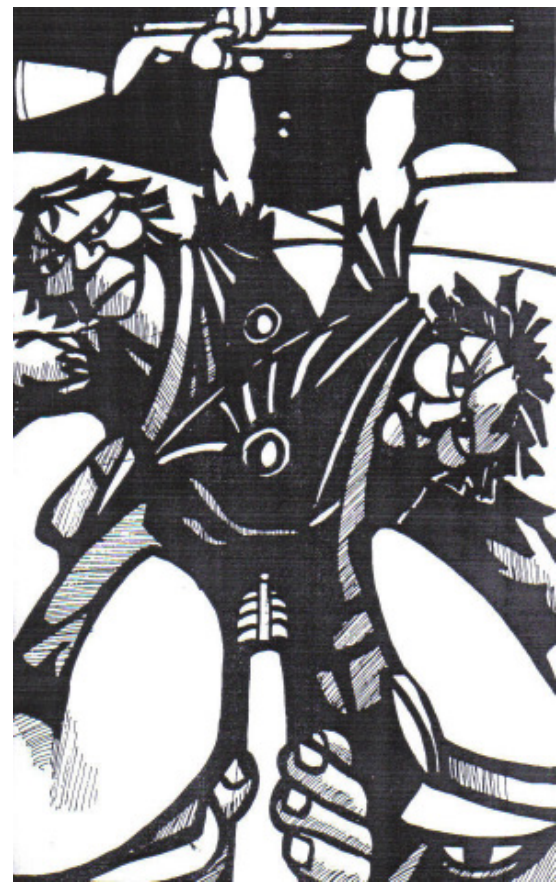

Extraído do cordel Os Irmãos Piriá, p. 39. 137), pode-se identificar Sebastião como o duplo de Orlando, o auxiliar mágico, ao mesmo tempo exterior e íntimo de seu protegido. As narrativas deixam a impressão de que no Caolho se concentra a força que contamina e fortalece o Gentil. É nessa força e nessa natureza encarnada no irmão Caolho que Gentil confia. Natureza que ele compreende como parte de si mesmo. É o que explica a identidade de destinos dos dois irmãos: um existe em função do outro. Caolho existe para salvar Gentil. Um irmão é guardião do outro; por isso têm que viver a mesma aventura. E embora a individualidade de Sebastião seja caracterizada de forma mais nítida, tudo que acontece com ele se comunica a Orlando ${ }^{42}$.

Voltemos à imagem dos dióscures do mito de Apolo. Tal como os dois irmãos gregos Eurytos e Kreatos, Sebastião e Orlando constituem manifestações diferentes de uma mesma força ou de um mesmo $\operatorname{ser}^{43}$. Apesar de terem direito cada qual a

${ }^{42}$ Sobre essa solidariedade bem como sobre a natureza dessa comunicação entre os duplos, cf. Durkheim (1989: 335-336).

${ }^{43}$ Para uma análise de uma versão portuguesa de um "Conto de dois irmãos" (Zweibrüdermärchen), ver Vieira da Mata (2003: 5-28). A hipótese defendida no artigo é a de que os dois irmãos representam o mortal e seu duplo (um espírito tutor), de forma que nessas narrativas populares - tal qual no "pensamento totêmico" (Durkheim 1989) e no sacrifício dos dióscures (Gehrts 1995) - não há vida possível sem um tutor, um auxiliar, alguém que conte com uma superioridade "mágica" (ou moral). Sobre a origem comum como definidora da essência comum dos dióscures, cf. Usener (1913) e Gehrts (1995: 20-27). Rank (1925), por sua vez, defende a origem do "mito do duplo" a partir do processo de defesa contra a morte. 
fisionomia, características e habilidades próprias, a vida de um é simulacro da vida do outro, de forma que a força simpática que une os Irmãos Piriás inviabiliza toda tentativa de individualização ${ }^{44}$. Até o discurso "oficial" confirma essa lógica da lenda:

Todos que conhecem a dupla dizem que Sebastião, o mais escuro e mais baixo, é o líder e o mais corajoso. O outro, Orlando, no assalto à fazenda de Raimundo Moreira, perto de Pirapama, na segunda-feira, também se mostrava bastante ousado, fazendo ameaças de morte, segundo o rapaz, filho do fazendeiro, que foi trancado no quarto por eles. Para a polícia, o fato demonstra que Orlando também foi tomado pelo entusiasmo do irmão, orgulhoso de seu sucesso no tiroteio com a polícia ${ }^{45}$.

Quase sempre, os dois são representados como um ser único. Uma unidade que, acredito, pode ser interpretada como um emblema do dever moral que um irmão tem de proteger o outro. De uma maneira tal, que, nas lendas, esse dever moral é representado como algo situado para além da vontade individual.

O que eu sei é que um deles foi preso e judiado na cadeia. Depois de sair de lá, ele se juntou com o irmão. O irmão, revoltado, jurou vingança. E aí saiu por aí matando policial. Não podia ver polícia que atirava. E não errava. Com civil não faziam nada não ${ }^{46}$.

Nesse contexto, o fato de Orlando e Sebastião serem irmãos permite um outro tipo de interpretação e classificação: ao ratificar o princípio (moral) segundo o qual irmãos se ajudam e protegem mutuamente, o que os interlocutores da lenda fazem é firmar uma hierarquia de valores específica que deve - idealmente - reger várias das relações sociais ${ }^{47}$. A qualidade dessa relação, expressa na linguagem do parentesco, reflete o vínculo moral entre esses dois numa sociedade onde o "parente" - em especial o irmão - tem importância estrutural ${ }^{48}$. A qualidade da relação entre os irmãos, determinada por valores morais específicos, se opõe, nas lendas, à qualidade do vínculo fazendeiro/polícia, que, ao contrário da obrigação moral que vincula Orlando e Sebastião, teria se dado em defesa de interesses privados às custas do direito de outros, ou seja, de forma imoral ${ }^{49}$.

${ }^{44}$ Em outras narrativas populares, os dois irmãos são gêmeos. Uma maneira de representar de forma ainda mais definitiva a simpatia (moral e mágica) entre os irmãos. A gemialidade como símbolo absoluto da não-individualidade: se a origem é comum, a essência é a mesma e os dois são um. Um ambicioso estudo comparativo da figura dos dois irmãos na tradição popular é feito por Ranke (1934).

45 A Noticia, 18/08/1978.

46 Momento narrativo com vizinhos, Sete Lagoas (18/11/2004).

47 O famoso bandido social Joaquim da Califórnia também tinha um irmão, morto por uma diligência do governo americano. Toda a justificativa para a reação de Joaquim da Califórnia contra os agentes da força governamental parte do princípio de que um irmão tem o dever de vingar, ajudar, proteger o outro. Cf. Evans (1989: 151). O mesmo vale para o primeiro epos da humanidade, o Gilgamesh, onde Uruk e Enkidu, os amigos-irmãos, vivem para cumprir a obrigação de proteção mútua. Segundo a epopéia, é essa obrigação moral que "transforma" os inimigos em irmãos. Moral da história: a unidade em fraternidade prescinde do laço de sangue. Sua garantia é moral, antes de qualquer outra coisa.

48 O parentesco, no caso, fornece uma moldura para os relacionamentos coletivos e para a definição do status social dos indivíduos.

49 Todavia, não acredito que se deva pensar os Irmãos Piriás como tipos que valorizam mais as relações pessoais que as obrigações sociais, como poderia sugerir uma análise inspirada nos 
Nota-se que os dois protagonistas da lenda são "feitos" pela comunidade de comunicação e que sua condição mágica é determinada pelo lugar moral que passam a ocupar no contexto social. Na relação entre magia e entendimento individual, quem destaca a diferença são os interlocutores das lendas. Extrai-se de sua condição (moralmente determinada) o argumento que justifica sua predestinação ao uso do sobrenatural como defesa contra as violências às quais são submetidos ${ }^{50}$. A autoridade dos Piriás está ancorada em forças especiais, extra-cotidianas e que, por isso mesmo tornam inócuo o recurso a explicações convencionais. Somente assim se entende porque a polícia, apesar de todos os recursos que tinha a seu dispor, não conseguia pegar dois joões-ninguém.

$\mathrm{X}:-[\ldots]$

G: - E o Sr. lembra de dizer por que é que eles se envolveram com a polícia?

A: - Parece que o pessoal dos Culego não queria eles lá na terra deles. Aí denunciô eles. Denunciô injusto. Mas era forte de poder.

G: - E aí eles foram presos!

A: - Foram. Mas depois foram soltos e aí começou.

G: - A polícia demorou a pegar os dois, né?

A: - Foi. Demorou muito. E aí começou a inventá história.

G: - As histórias de que eles dois tinham o corpo fechado?

A: - Ah! Mas isso é conversa. Falavam que eles tinha oração que protegia eles. Que o pai fez. Mas não é isso não.

G: - O que é então?

A: - A polícia é que não conseguia acompanhá os dois no mato.

$\mathrm{X}:-[\ldots]^{51}$.

A demora e a dificuldade da polícia em apanhar dois "peões de roça" exigia explicação ${ }^{52}$. A racionalidade mágica então é acionada para esclarecer uma situação que não se deixava explicar de outra maneira. Apesar da insistência dos interlocutores em justificar que "não crêem" que os Piriás fossem realmente figuras encantadas, em praticamente todas as narrativas as pessoas atribuem as habilidades dos protagonistas a fatores sobrenaturais e assim, justificam seu "Sucesso" ${ }^{53}$. Nas lendas dos Piriás, a magia vence toda a técnica.

"tipos místicos" de Turner (1974: 135). Como temos demonstrado, os Piriás são tidos como tipos engajados em uma verdadeira luta por reconhecimento (Honneth 2003), onde exigências quanto a obrigações sociais - e/ou morais - são feitas de forma concreta, para além do mero gesto ritual. Embora não se negue aqui que, enquanto personagens de lendas, os Piriás possuam um caráter liminar nos termos de Turner (1974: 117, 133, 156 e 159).

${ }^{50}$ Nesses termos, os Piriás evidenciariam a validade da teoria maussiana da magia (Mauss 2003), segundo a qual o fenômeno individual nasce do fato social. Também no caso dos dois irmãos de Sete Lagoas, magia é fato de opinião.

${ }^{51}$ Momento narrativo registrado em 04/01/2007.

52 "Ninguém está admitindo que um aparato policial tão grande e tão equipado deixasse escapar os dois salteadores. Há dúvidas quanto ao trabalho da polícia, mas pode-se afirmar que todos os empregados na busca se empenharam com suas possibilidades. Quando havia uma pista, eles iam conferir, só que não encontravam nada" (Estado de Minas, 11/08/1978).

${ }^{53}$ Apesar de sempre recorrerem a ela na construção de suas narrativas, alguns interlocutores parecem desqualificar a explicação de tipo mágico. A intenção seria resguardar-se ante uma possível ridicularização por parte daqueles que não compartilham do mito. A questão central, porém, é outra: por que, a despeito de não "acreditarem", tais interlocutores continuam a evocar o caráter mágico dos Piriás? Não há como fugir à questão da função social-moral da lenda. 
$\mathrm{X}:-[\ldots]$

G: - O Sr. falou de tecnologia, lembrei que na época dos Piriá usaram até helicóptero?

A: - Não, que acho que nem tinha isso na época. Usaro foi um aviãozinho, desses tecoteco que um fazendero emprestô pra polícia. Os dono da cooperativa onde os Piriá apanharo umas galinha pra comê.

B: - É! Mas veio até visão de Raio X do exército dos Estados Unidos pra enxergá os Piriá no escuro. Não valeu titica. Os home sumia mato adentro e quem é.

G: - Sumia que nem mágica.

B: - Que nem feitiço. Mas não era nada disso não. Eles era é esperto mesmo e conhecia a redondeza. Não tinha medo do mato e sabia se virá.

G: - Já a polícia...

B: - É melhó deixá pra lá.

[risos]

$\mathrm{X}:-[\ldots]^{54}$.

O mesmo pode ser observado no caso dos Irmãos Voitka, da Estônia (Kalmre 2005). Os Voitka também eram considerados encantados e tiveram suas fugas espetaculares explicadas magicamente em inúmeras lendas, as quais narram seus feitos heróicos no decorrer de 14 anos (1986-2000) de perseguição pelas autoridades russas e depois estonianas. Os dois irmãos podiam, por exemplo, se transformar em animais e conversar com eles. O saber de que dispunham e que garantiu por tanto tempo sua sobrevivência nas florestas da Estônia é transformado, no imaginário popular, em poder sobrenatural. Os irmãos Ülo e Aivar Voitka foram transformados em verdadeiros "forest brothers". Eles se protegiam mutuamente naquilo que foi identificado como uma verdadeira guerra contra as autoridades locais, em especial a polícia russa, que pretendia submetê-los ao serviço militar soviético ${ }^{55}$.

Contudo, tanto nas lendas dos Piriás quanto nas dos Voitka, o que está em questão não é o estabelecimento de uma equivalência entre magia e técnica. O poder dos dois irmãos é considerado superior ao da polícia. De forma que a divergência de interesses e, sobretudo, de valores se traduz em assimetria de poder. A técnica da polícia aparece neutralizada pela condição mágica dos Piriás - e também dos

${ }^{4}$ Momento narrativo registrado em 04/01/2007. Os jornais da época não se cansavam em enumerar os recursos da polícia. Cavalaria, cães adestrados, rádios, aparelhos de visão noturna, coletes à prova de bala, etc. O destaque ao aparato técnico da polícia vinha estampado já nos títulos das reportagens. O uso de helicóptero e avião mereceu destaque especial: "PM perto dos Piriás. Até helicóptero na operação" (A Notícia, 16/09/1978); "Polícia usa avião contra loucos do Paredão" (Estado de Minas, 15/09/1978); "Polícia usa teco-teco na caçada e irmãos Piriás atacam em Corinto" (Estado de Minas, 12/12/1978). Causou sensação também a vinda, dos Estados Unidos, de um "aparelho para investigações à noite, dotado de raios ultravioleta" cujas instruções de uso tiveram que ser traduzidas pessoalmente pelo capitão da polícia, segundo informa a reportagem no jornal A Notícia (17/08/1978).

55 Segundo a lenda, os Voitka fugiram do serviço militar. Uma fuga que é descrita como um feito de heroismo, mas que comporta também um significado político. A figura dos dois irmãos foi instrumentalizada para se transformar em link associativo para as aspirações de independência da Estônia frente ao domínio soviético. Para Eda Kalmre (2005), trata-se de um caso típico de justaposição das características do herói tradicional e do "modern hero media". A comparação entre os Irmãos Piriás e os Irmãos Voitka demandaria, em si, uma investigação à parte. Além de "media legends", os Piriás da Estônia também viraram filme, quadrinhos, documentário, além de personagens de lendas contemporâneas. E como os Piriás, promoveram o debate público sobre valores e formas de distribuição de reconhecimento social. 
Voitka -, e isso, não apenas nas lendas. É o que se pode perceber na chamada de uma reportagem do jornal Em Tempo.

Contra as cartucheiras dos irmãos Piriás, a Polícia Militar armou uma praça de guerra no cenário imortalizado pelo escritor Guimarães Rosa. 150 soldados, cavalos, cães rastreadores, metralhadoras, fuzis, um helicóptero, um avião teco-teco e até um sofisticado aparelho de raios infravermelhos para a observação noturna, muito utilizado pelos americanos no Vietnã. [...] No entanto, nas dez vezes em que eles foram localizados, ou a polícia era irremediavelmente abatida na troca de tiros ou simplesmente ludibriada ${ }^{56}$.

A ilustração que acompanha a reportagem supracitada reforça essa qualidade sobrenatural dos Piriás. A imagem dos dois tem algo de etérea. Só assim se explica que os Piriás literalmente escapem por entre os dedos de seu perseguidor, um policial

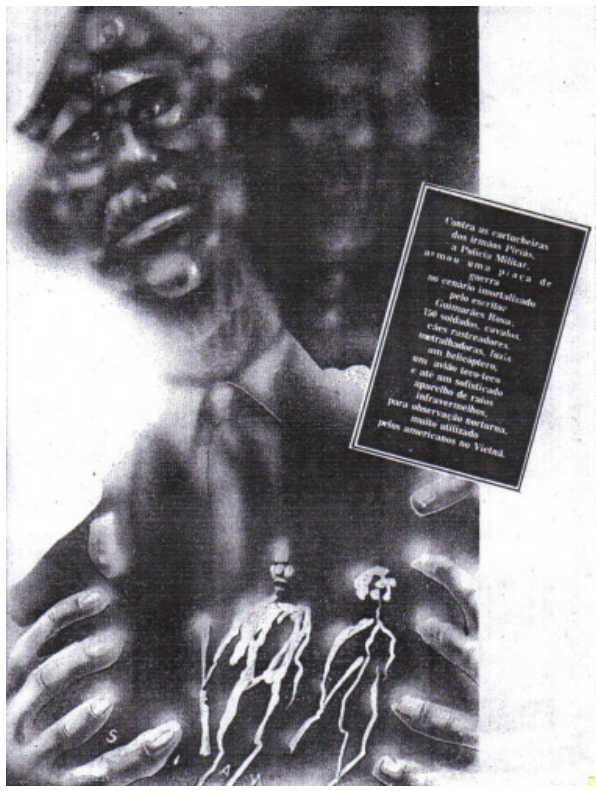

Extraído do jornal Em Tempo, dezembro de 1978. como disfarce escolhido pela morte.

O acesso privilegiado ao sobrenatural permite a Orlando e Sebastião vencer na lenda a polícia e seu aparato técnico. Pouco importa que o mérito caiba às habilidades de mateiros dos dois irmãos e à sua impressionante perícia no manuseio de armas de fogo; a justificativa para as fugas espetaculares dos dois se faz sempre, ou quase sempre, em outros termos:

- "Eles dão dois passos pra frente e um pra trás. Assim, vão dando voltas e fugindo. Quando ele gritou, eu rodei o corpo e a bala passou raspando no meu braço..."

Quem conta isto é o cabo Varonil, destacado de Sete Lagoas, relatando o encontro da patrulha com os irmãos Orlando e Sebastião Patrício, do qual resultou a morte de um sargento e um soldado, além de ferimentos gravíssimos em outro militar. A dupla Orlando e Sebastião acabou de se transformar em lenda, pelo menos para a população rural de seis municípios próximos a Sete Lagoas. O cabo Varonil, experimentado policial de idade já madura, a exemplo de muitos de seus colegas, confirma que os bandidos rurais "são bons de tiro e conhecem muito bem a região onde vivem", o que facilita a fuga. [...] O comandante da $3^{\underline{a}}$ Companhia do $3^{\circ}$ Batalhão da Polícia Militar, capitão José Ivo Gomes de Oliveira participou pessoalmente das operações de captura que resultaram nas mortes de seus comandados [...]. Ele disse que Orlando e Sebastião ficaram costa a costa e, enquanto um municiava as armas utilizadas, o outro disparava tendo, inclusive, esca-

\footnotetext{
${ }^{56}$ A reportagem foi publicada em dezembro de 1978 (na cópia a que tivemos acesso não consta a data exata). Importante frisar que o poder mágico como garantia de fuga dos dois irmãos aparece aqui e ali nas reportagens sobre o caso. Cf. "Polícia cerca Macacos e os irmãos somem no mato" (Estado de Minas, 10/08/1978), "Aguaceiro e escuridão salvam os Piriás" (Estado de Minas, 24/11/1978) e "Mais que Lampião" (Em Tempo, ?/12/1978). Para o conceito de "fuga mágica", cf. Campbell (1999: 190-199).
} 
pado de rajadas de metralhadoras quase a queima roupa. [...] Para o povo, não contam os conbecimentos empiricos de maneiras de subsistir nas selvas [...], o perfeito domínio da topografia muito acidentada, com excelentes esconderijos [...]. Principalmente para Sete Lagoas, uma cidade em polvorosa com a presença dos criminosos na região e a movimentação policial fora do comum, os bandidos têm parte com o capeta ${ }^{57}$.

Entretanto, o que parece ser magia, acionada para fazer frente à técnica do aparato policial militar, é na verdade apenas uma modalidade de técnica mais eficiente. Diferentemente de Arnold Gehlen (s/d: 22-26; 1963: 79-92), que explorou de forma tão instigante essa íntima relação entre magia e técnica, vendo na segunda um substituto moderno da primeira, penso que as lendas sobre os Piriás não tratam da distinção entre magia e técnica, como coisas passíveis de se substituir mutuamente. Ali a relação entre ambas é de outra ordem: em vez de substituição de uma pela outra, o que temos é o recurso técnico traduzido em termos mágicos, já que o que confere à técnica qualidade mágica é, antes de tudo, o grau de sua eficácia. Ou seja, quanto melhor funciona, mais mágica a técnica parece. Por isso o conhecimento simples que garante a sobrevivência dos Piriás frente às investidas da polícia é traduzido em termos da linguagem da magia, ao passo que toda a sofisticação do aparato policial é reduzida à condição de farsa, encenação, exatamente porque não funciona.

Vejamos mais um exemplo que ilustra bem como se dá essa tradução da técnica em magia por meio da avaliação do grau de eficiência. O Estado de Minas, depois de registrar a insatisfação da população com a ineficiência da polícia, refere-se aos cães rastreadores empregados na caçada:

As condições dos cães rastreadores da Polícia Militar foram, também, bastante questionadas entre o povo e os próprios policiais. Ninguém conseguiu entender como os animais, especializados em buscas, após ter contato com objetos dos irmãos Piriás, não conseguiram localizá-los poucas horas após o tiroteio ${ }^{58}$.

Dois interlocutores deram-me, sem qualquer embaraço, sua visão do que acontecia.

$\mathrm{X}:-[\ldots]$

B: - Veio batalhão de choque de Diamantina [...]. Veio cavalaria, veio canil [...]. Foi justamente na época que surgiram os cães adestrados da polícia. E não deu conta?

A: - Quando achava roupa deles, passava a roupa deles pro cão...

B: - E nem assim!

A: - Diz que passava embaixo das árvores, olhava pra cima, latia, latia e ninguém via. Isso a gente via muita gente contá, que passava a roupa deles nos cachorro, que os cachorro chegava debaixo da árvore, ficava doido debaixo da árvore, gritando debaixo da árvore, querendo subí e ninguém enxergava ninguém na copa das árvores.

B: - Não tem lógica.

A: - Eles ficava invisível na oração. Era isso que acontecia. Bom, ao menos é o que o povo dizia.

$\mathrm{X}:-[\ldots]^{59}$.

Nas lendas, a ação dos Piriás é reação. Os dois irmãos reagem (de forma violenta) à ausência de um fundo ético capaz de impor regras consensuais a todos - rea-

\footnotetext{
57 Diário da Tarde (07/08/1978). O grifo é meu.

58 Estado de Minas (11/08/1978).

59 Momento narrativo registrado em 05/01/2007, em Sete Lagoas.
} 
gem, pois, àquela ausência de institucionalização da esfera moral de que fala Jessé Souza (2000; 2003). Essa "prática violenta da moral" surge, na lenda, como necessária diante da impossibilidade de uma prática "não-violenta da moral" ${ }^{60}$. Se o Estado idealmente deveria deter monopólio da violência física, o que a lenda demonstra é que as coisas no mundo da vida não são bem assim.

Os irmãos encenam uma violência estereotipada em episódios decisivos que, ao mesmo tempo que exaltam a coragem e a eficiência dos Piriás, sancionam seu code moral. Os dois irmãos são tidos como expressão de um tipo específico de modus vivendi, de maneira que sua conduta é julgada sempre legítima e perfeitamente razoável, como se o conflito com a polícia representasse a possibilidade de autoconsciência desses personagens, além da objetivação das contradições que marcam a forma de interação no meio social. De tal maneira que a forma de agir dos Piriás é transformada em sinal social através do qual eles podem ser classificados. O plus ético-moral de suas ações pode ser lido como reverso do conformismo: sua (re)ação é descrita como uma explosão (eventual e violenta) da vontade individual reivindicando reconhecimento social.

Essa propensão à violência - mesmo que não adquira uma dimensão coletiva de intenção transformadora, mantendo-se confinada à esfera individual - é apresentada na lenda como um problema para a ordem estabelecida. Na lenda deixa-se claro que, ao errar o alvo e agir contra trabalhadores, o que a polícia faz é dar oportunidade para a manifestação violenta por parte daqueles que respondem à violência com violência. De um lado, uma violência (policial) ilegítima. De outro, o exercício legítimo da violência: diferentemente da polícia, eles nunca "erram o alvo" ${ }^{61}$.

Todavia, e apesar de todo o fascínio e da força de que desfruta a imagem social de Orlando e Sebastião, não devemos nos esquecer que o caráter dos Piriás, nas lendas, é uma imputação; uma identidade virtual criada para eles no decorrer da narração a partir da sua condição de trabalhadores. Ao passo que tal condição é que permite que todas as ações dos dois sejam descritas (e interpretadas) em referência a expectativas morais específicas. Essas expectativas morais, por sua vez, adquirem caráter normativo, já que a ação dos Piriás é apresentada como uma forma de manutenção de uma visão específica de mundo. A narrativa é toda ela construída em termos do que concretiza ou desaponta aquelas expectativas. Por isso, ao mesmo tempo, que as lendas fazem referência às circunstâncias de cada ação, elas o fazem descrevendo o caráter, os motivos e as intenções dos agentes qualificando moralmente todas as suas ações, toda sua personalidade e todas as circunstâncias que cercam sua trajetória, inclusive quando se trata da descrição de sua morte.

Para a grande maioria das pessoas, os Piriás não morreram. A explicação para isso é clara: eles eram moralmente invulneráveis e, por isso, "duros de matar". Ao afirmar que os Piriás não morreram, os interlocutores da lenda falam da morte como algo

\footnotetext{
${ }^{60}$ Nesse sentido, a não-violência tem mais a ver com o grau de legitimidade de uma ação do que com um ideal de ausência total da violência.

${ }^{61}$ A nos fiarmos em Rifiotis (1997), nossa referência neste aspecto, a violência dos Piriás configuraria uma "sobrevivência" em plena modernidade, um "arcaismo social". Mas, na verdade, a situação de violência nas lendas não é entendida (ou apresentada) como uma ruptura na experiência social moderna. Não está fora do lugar, nem do tempo. Tanto é assim que essas histórias sobre os Piriás continuam vivas em Sete Lagoas ainda hoje.
} 
que pode ser evitado, como se morrer ou não se tratasse de uma escolha moral por parte de sujeitos morais. Como exemplo do que estou afirmando, posso evocar o episódio, ou a versão, em que os Piriás teriam matado a própria mãe. Nas narrativas que seguem esse enredo, os dois irmãos sempre morrem: é como se somente essa forma paroxística de crime hediondo fosse capaz de finalmente romper sua blindagem moral.

Mas há os que dizem 'que sempre será seu destino: vão continuar perseguidos pelos homens, acuados como feras, até o fim de seus dias, e quando morrerem vão pagar suas penas eternamente nas garras do diabo', porque afirmam que "eles mataram a própria mãe" ${ }^{62}$.

Essa relação entre vulnerabilidade moral e finitude, observada e analisada brilhantemente por Honneth (2003: 93-94), pode ser identificada em todas as narrativas sobre os Piriás. Nos casos em que os interlocutores, com base no noticiário, "sabem" que os Piriás foram mortos pela polícia, a morte dos dois é justificada com base no recurso da emboscada, da traição.

Vai que o João Viana mantinha o fogão aceso, com as labaredas do fogo sendo avistadas de longe. Enquanto isso, os policiais ficaram escondidos dentro do tal tanque, ali do lado. No que os Piriá vieram, um chegando na casa ao modo de pedir fogo para acender o pito, o Zé Lapinha deu a volta e avisou a polícia. Em quando esse um saía, já passando debaixo da cerca de arame do fecho da linha, no meio do capim, os policiais abriram fogo. Não teve escapatória! Ele arriou em cima do rastro! O outro escapuliu, indo pra o lado do rancho do Chico de Aleixo, sem por onde escapar. Pois vinha polícia de tudo quanto é lado ${ }^{63}$.

Reza o dito popular que "herói, só morto". Sendo assim, se os Piriás estão mortos; longa vida aos Piriás. É como se aqueles que narram as façanhas de Orlando e Sebastião precisassem dos Piriás como signo, um verdadeiro esquema para o debate público sobre os valores que regem as relações sociais num dado contexto. É um code moral que se preserva na imagem dos dois, mesmo mortos. Sendo assim, apesar de sua finitude, Orlando e Sebastião continuam a ser percebidos como moralmente invulneráveis: heróis, portanto. E como heróis, representam o ideal moral daqueles que narram suas histórias.

\section{BIBLIOGRAFIA CITADA}

Campbell, J. 1999. Der Heros in tausend Gestalten. Frankfurt am Main/Leipzig: Insel Verlag. Douglas, M. 1976. Pureza e Perigo. São Paulo: Perspectiva.

Durkheim, E. 1989. As formas elementares da vida religiosa. São Paulo: Paulinas.

\footnotetext{
${ }^{62}$ Jornal A Gazeta (09/08/1978).

${ }^{63}$ Quem conta é José Dias, 80 anos, conhecido pela alcunha de Milunga, vaqueiro em Contria, região onde os Piriás teriam enfrentado a polícia pela última vez. Quem registrou a memória do Milunga fora Francisco Timóteo, em sua novela Os Irmãos Piriás (2002:104) conforme o autor mesmo me disse por ocasião de uma conversa em fevereiro de 2004 . Francisco Timóteo faloume ainda das entrevistas que fez antes de escrever sua novela e prometeu-me acesso ao material. O que infelizmente não foi possível, já que, pouco tempo depois, veio a falecer.
} 
Evangelista, J. e Camargos, T. 1979. Os Irmãos Piriás: uma guerra no sertão. Belo Horizonte: Centro Mineiro de Cultura Popular.

Evans, J. 1989. "The Legend of Joaquin, 'the Celebrated California Bandit', en Bennett, G. e Smith, P. (eds.), The Questing Beast: 145-163. Sheffield: Sheffield Academic Press.

Gehlen, A. s/d. A alma da era da técnica. Problemas de psicologia social na sociedade industrializada. Lisboa: Livros do Brasil.

Gehlen, A. 1963. "Über die Verstehbarkeit der Magie”, en Studien zur Anthropologie und Soziologie. Neuwied: Luchterhand.

Gehrts, H. 1995. Das Märchen und das Opfer: Untersucheungen zum Europäischen Brüdermärchen. Bonn: Bouvier.

Girard, R. 1990. A violência do sagrado. São Paulo: UNESP/Paz e Terra.

Goffman, E. 1982. Estigma. Notas sobre a manipulação da identidade deteriorada. Rio de Janeiro: Zahar.

Honneth, A. 2003. Luta por reconbecimento. São Paulo: Editora 34.

Kalmre, E. 2005. "The saga of the Voitka Brothers in the Estonian Press". Folklore 29. Disponível em: http://www.folklore.ee/folklore/vol29/voitka.pdf (Acesso 17/05/2006).

Lindahl, C. 1996. "Psychic Ambiguity at the Legend Core", en Bennett, G. e Smith, P. (eds.). Contemporary Legend: a reader. New York/London: Garland Publishing.

Mauss, M. 2003. "Esboço de uma teoria geral da magia", en Sociologia e antropologia. São Paulo: Cosac Naify.

Morin, E. 1997. O bomem e a morte. Rio de Janeiro: Imago.

Propp, V. 1997. As raízes históricas do conto maravilhoso. São Paulo: Martins Fontes.

Rank, O. 1925. Der Doppelgänger. Wien: Psycho Verlag.

Ranke, K. 1934. Die Zwei Brüder. Helsinki: DSUK.

Rifiotis, T. 1997. "Nos campos da violência: diferença e positividade". Primeira Mão 19: 1-20.

Röhrich, L. 1966. Sage. Stuttgart: Metzlersche Verlagsbuchhandlung.

Schenda, R. 1993. "Folklore und Massenkultur". Schweizerisches Archiv für Volkskunde 87: 15-27.

Stehr, J. 1998. Sagenhafter Alltag. Frankfurt am Main: Campus Verlag.

Souza, J. 2000. A modernização seletiva. Brasília: Editora da UNB.

Souza, J. 2003. A construção social da subcidadania. Belo Horizonte: Editora da UFMG.

Timóteo, F. 2002. "Os Irmãos Piriá", en Desavenças e avenças. Sertão e burgas. Sete Lagoas: Instante.

Turner, V. 1974. O processo ritual. Petrópolis: Vozes.

Usener, H. 1913. Arbeiten zur Religionsgeschichte. Leipzig/Berlin: B. G. Teubner.

Vieira da Mata, G. 2003. "A Torre de Babilônia: interpretações para um Zweibrüdermärchen". Lusorama. Zeitschrift für Lusitanistik 53 (1): 5-28.

Fecha de recepción: 4 de febrero de 2011

Fecha de aceptación: 24 de octubre de 2011 